\title{
Only pharmacological doses of atrial natriuretic peptide affect intestinal ion transport in non-volume expanded rats
}

\author{
R Lübcke, J Brunner, F A Hutcheson, G O Barbezat
}

\begin{abstract}
Pharmacological doses of atrial natriuretic peptide were infused into rats to study its effect on intestinal transport. Saline control or two concentrations of rat $\alpha$ atrial natriuretic peptide $(0.06$ or $1.0 \mathrm{nmol} / \mathrm{min} / \mathrm{kg})$ were administered intravenously $(1 \mathrm{ml})$ over one hour. Jejunal net transport of water and electrolytes was measured with a plasma-like luminal electrolyte solution using a 'closed loop' technique. Distal colonic potential difference and arterial blood pressure were monitored continuously. Blood samples for analysis of plasma atrial natriuretic peptide concentrations were taken at the end of the experiments. Plasma concentrations were increased (mean (SD) $(2 \cdot 1)(0.5)$ and $24.0(1.1) \mathrm{nmol} / 1$ respectively) compared with the controls $(0.023(0.016) \mathrm{nmol} / \mathrm{l})$. Blood pressure dropped by $30 \%(\mathrm{p}<0.05)$ in both groups of rats receiving atrial natriuretic peptide but remained unchanged when control saline was infused. Jejunal net absorption was reduced $(p<0.01)$ only in animals receiving the higher concentration of peptide $\left(\mathrm{H}_{2} \mathrm{O}\right.$ from 173 (33) to $64(69) \mu \mathrm{l} \cdot \mathrm{h}^{-1} \cdot \mathrm{cm}^{-2}, \mathrm{Na}$ from $25 \cdot 7(5 \cdot 3)$ to $\left.10.9(8.9) \mu \mathrm{mol} \cdot \mathrm{h}^{-1} \cdot \mathrm{cm}^{-2}\right)$. Distal colonic potential difference was not affected by atrial natriuretic peptide. In conclusion massive doses of atrial natriuretic peptide are required to produce any change in intestinal salt and water transport in normal, non-volume expanded rats; these effects could be a nonspecific or 'toxic' response.
\end{abstract}

The effect of extracellular fluid expansion on the kidney and intestine has been known for some time. ${ }^{12}$ Richet and Hornych showed that extracellular fluid expansion diminished reabsorption of sodium in the proximal tubule and in the jejunum. ${ }^{2}$ They also excluded any role of angiotensin and aldosterone and they claimed general humoral or physical factors to be responsible for the observed phenomena. Further studies showed that this was a short acting mechanism which probably acted on sodium transport processes. The discovery of atrial natriuretic peptide in $1978^{3}$ provided a putative mediator for this effect. Although atrial natriuretic peptide is very active in the renal tubule, data on its effects on intestinal water and electrolyte transport are still contradictory. Increased absorption,${ }^{4}$ reduced absorption, and even secretion ${ }^{5-8}$ have been described in laboratory animals, and no effects could be found in humans. ${ }^{910}$ Results have been confused by the wide range of doses used in these studies, as well as by experimental variables such as nonstandardisation of volume loading.

In our preceding study using pathophysiological doses of atrial natriuretic peptide in normal human volunteers no effect on small intestinal electrolyte transport and potential difference was found. ${ }^{10}$ The present study was therefore designed to investigate the effects of two pharmacological doses of atrial natriuretic peptide on jejunal transport and colonic potential difference in the non-volume expanded rat. Systolic blood pressure was monitored to serve as a measure of bioactivity of the synthetic rat $\alpha$ atrial natriuretic peptide.

\section{Methods}

ANIMALS

Male Wistar rats (Animal Breeding Station, Dunedin, NZ) with an average body weight of $250 \mathrm{~g}$ were used in the experiments. The rats received a standard diet ( $\mathrm{F} 49$, Animal Breeding Station, Dunedin, NZ), containing (g/kg): $\mathrm{Na}^{+}$ $3 \cdot 2$ and $\mathrm{K}^{+} 7 \cdot 6$, and had free access to tap water.

\section{EXPERIMENTAL PROCEDURE}

After overnight fasting rats were anaesthetised with pentobarbitone sodium (Ceva Chemicals, Australia: $60 \mathrm{mg} / \mathrm{kg}$ body wt intraperitoneally). Animals were placed on a thermoregulated surgical table and body temperature kept constant at $37^{\circ} \mathrm{C}$. After a tracheostomy was performed an intravenous line was placed into the right jugular vein and connected to a peristaltic pump (Ismatec 7619-32, Switzerland). The abdomen was then opened through a midline incision and both a $10 \mathrm{~cm}$ proximal jejunal loop and the distal colon were rinsed with the test solution (plasma-like electrolyte solution containing (mmol/l) $\mathrm{Na}^{+} 144, \mathrm{~K}^{+} 4, \mathrm{Ca}^{2+} 1 \cdot 25$, $\left.\mathrm{Mg}^{2+} 0.75, \mathrm{Cl}^{-} 127, \mathrm{HCO}_{3}^{-} 25\right)$. A polyethylene catheter (outside diameter $1.5 \mathrm{~mm}$ ) filled with the solution served as a potential difference measuring electrode and was positioned with its sensing port $6.5 \mathrm{~cm}$ proximal to the anus, and $0.5 \mathrm{ml}$ of the test solution was instilled into the colon to provide sufficient electrical contact to the mucosal surface. The stripped tail of the rat, bathed in saline, served as an indifferent electrode. Connections from the colon to an Electrometer (Keithley 610C, Cleveland, Ohio, USA) were made using $\mathrm{KCl}$-agar bridges and $\mathrm{Ag}-\mathrm{AgCl}$ electrodes. Colonic potential difference was recorded throughout the experiment (Rikadenki B281-HS, Kogyo, 


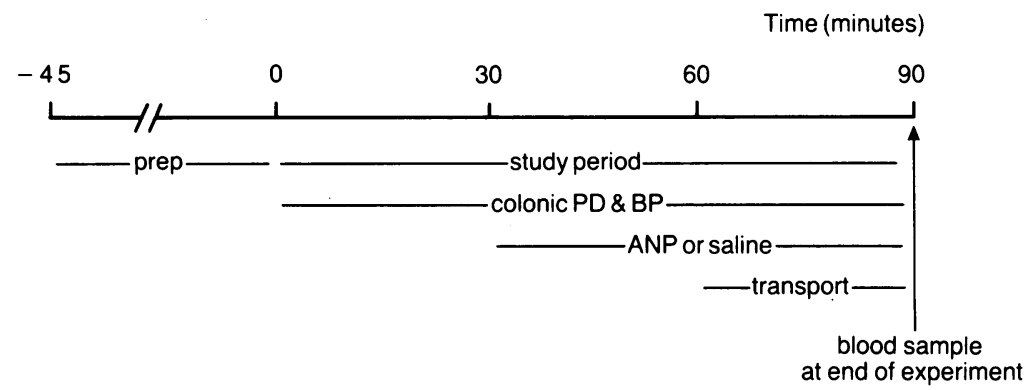

Figure 1: Study design. Time for preparation (prep) covered 45 minutes ( -45 to 0 min). Distal colonic potential difference (colonic $P D$ ) and systolic blood pressure $(B P)$ were continuously monitored over the study period (0 to $90 \mathrm{~min}$ ) a atrial natriuretic peptide (ANP) or vehicle (saline) were given intravenously (30 to $90 \mathrm{~min}$ ) and jejunal net ion and water transport was measured during the final 30 minutes of the study $(60$ to $90 \mathrm{~min})$. At the end of the experiment blood was drawn from the aorta for plasma atrial natriuretic peptide analysis (90 min).

Japan). Blood pressure was measured at 10 minute intervals by sphygmomanometry."

Atrial natriuretic peptide (Sigma Chemical, St Louis, Missouri, USA) was dissolved in isotonic saline and stored at $-80^{\circ} \mathrm{C}$ in $1.2 \mathrm{ml}$ aliquots in polyethylene tubes. The doses were allocated blindly on the day of study after a randomised numbered code for three experimental groups: group 1 to receive isotonic saline (control, $\mathrm{n}=$ 12); group $2 \alpha$ atrial natriuretic peptide $(0.06$ $\mathrm{nmol} / \mathrm{min} / \mathrm{kg}$ rat, $\mathrm{n}=10)$; group $3 \alpha$ atrial natriuretic peptide $(1.0 \mathrm{nmol} / \mathrm{min} / \mathrm{kg}, \mathrm{n}=10)$. At the end of the study two control rats were discarded because of leakage of the intravenous line and one rat from each peptide series died during peptide infusion. Finally, data from 10 control rats and nine animals from both the lower and the higher peptide group were analysed.

Figure 1 shows the study design. The preparation procedure was usually completed within 45 minutes. After 30 minutes of basal recordings an intravenous infusion of saline or atrial natriuretic

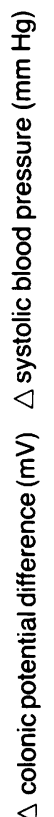

${ }^{10}[\quad$ ANP (groups $2 \& 3$ ), saline (group 1)
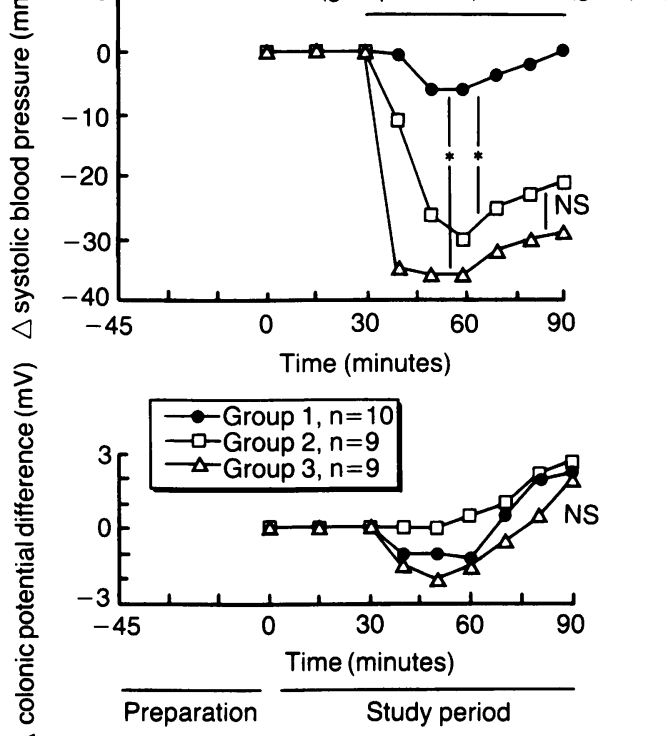

Figure 2: Effects of intravenous $\alpha$ atrial natriuretic peptide ( $A N P$, groups 2 and 3) and saline (group 1) on systolic blood pressure and distal colonic potential difference. Initial simila baseline readings. (0-30 min) were followed by a significant drop $\left({ }^{\star} p<0.05\right)$ in blood pressure in the ANP groups. (2 and 3). Distal colonic potential difference was not affected by intravenous ANP.
Effect of atrial natriuretic peptide on jejunal transport $\left(\emptyset_{\text {net }}\right)$ in the rat (Mean $(S D)$ )

\begin{tabular}{|c|c|c|c|c|c|}
\hline \multirow[b]{2}{*}{ Group } & & \multirow{2}{*}{$\frac{\mu l \cdot h^{-1} \cdot \mathrm{cm}^{-2}}{\mathrm{H}_{2} \mathrm{O}}$} & \multicolumn{3}{|c|}{$\mu \mathrm{mol} \cdot \mathrm{h}^{-1} \cdot \mathrm{cm}^{-2}$} \\
\hline & & & $\mathrm{Na}^{+}$ & $K^{+}$ & $\mathrm{Cl}^{-}$ \\
\hline $\begin{array}{l}1 \\
2 \\
3\end{array}$ & $\begin{array}{r}10 \\
9 \\
9\end{array}$ & $\begin{array}{c}173(33) \\
157(52) \\
64(69)^{\star}\end{array}$ & $\begin{array}{l}25 \cdot 7(5 \cdot 3) \\
23 \cdot 9(7 \cdot 3) \\
10 \cdot 9(8 \cdot 9)^{\star}\end{array}$ & $\begin{array}{r}0.29(0.30) \\
0.25(0.26) \\
-0.44(0.37)^{\star}\end{array}$ & $\begin{array}{c}19 \cdot 7(5 \cdot 1) \\
17 \cdot 7(6 \cdot 7) \\
5 \cdot 6(8 \cdot 4)^{\star}\end{array}$ \\
\hline
\end{tabular}

peptide was started for one hour (total volume $1 \mathrm{ml}$ ); the first 30 minutes of this were an equilibration period, after which the jejunal segment was filled as a 'closed loop' with $2 \mathrm{ml}$ of the test solution containing polyethylene glycol $\left(\mathrm{PEG}_{4000}, 6 \mathrm{~g} / \mathrm{l}\right)$ as a volume marker. On completion of the 90 minute study, samples were taken from the jejunal loop for analysis of ion fluxes and blood drawn from the aorta for determination of plasma atrial natriuretic peptide concentrations. The blood was collected in chilled ethylenediamine tetra-acetate glass tubes, centrifuged, and the plasma stored at $-80^{\circ} \mathrm{C}$.

\section{ANALYTICAL METHODS}

Jejunal net ion fluxes were calculated using the formula:

$$
\emptyset_{\text {net }}=\frac{C_{i} V_{i}-C_{f} V_{f}}{A t}
$$

where $C_{i}$ and $C_{f}$ and $V_{i}$ and $V_{f}$ are the concentrations and volumes of electrolyte at the beginning (i) and end ( $f$ ) of the test period respectively. The surface area (A) of the intestinal segment was determined using a standardised technique, ${ }^{12}$ and $(t)$ was the time of the sampling period. Sodium and potassium concentrations were determined using a flame photometer (Radiometer Copenhagen, FLM3). Chloride was measured by coulimetric titration (Radiometer Copenhagen, CMT 10). PEG $_{4000}$ was analysed by a turbidometric method. ${ }^{13}$ Plasma immunoreactive atrial natriuretic peptide was measured in plasma extracts as previously described. ${ }^{3}$ The plasma concentrations in the rat had to be corrected by a factor of $1 \cdot 42$, because human $\alpha$ atrial natriuretic peptide standards were used which show a $142 \%$ crossreactivity with rat $\alpha$ atrial natriuretic peptide. ${ }^{14}$

\section{STATISTICS}

Results are expressed as means (SD). Statistical analyses were performed using Student's $t$ test for unpaired values and one way Anova with multiple range test (Duncan procedure); $\mathrm{p}$ values $<0.05$ are considered significant.

\section{Results}

The body weight of the animals was similar in the three groups (group 1: 247 (11), group 2: 249 (9), group 3: 245 (10) g). Plasma atrial natriuretic peptide concentrations were within normal 
limits in group $1(0.023(0.016) \mathrm{nmol} / \mathrm{l})$ but were appreciably raised in the rats infused with atrial natriuretic peptide (group 2: $2 \cdot 1(0 \cdot 5)$, group 3: $24.0(1 \cdot 1) \mathrm{nmol} / \mathrm{l})$. Baseline systolic blood pressures did not differ significantly between the three groups (group 1: 99 (8), group 2: 103 (21), group 3: 103 (6) $\mathrm{mm} \mathrm{Hg}$ ). Atrial natriuretic peptide significantly decreased blood pressure by about $30 \%$ in both groups $(\mathrm{p}<0.05)$, reaching similar low values within 30 minutes of infusion, while the controls only showed slight effects on blood pressure (Fig 2).

Colonic potential difference was not affected by atrial natriuretic peptide (Fig 2). Similar initial readings (group 1:23·7 (8.6), group 2: $25 \cdot 3$ $(10 \cdot 8)$, group $3: 25 \cdot 4(7 \cdot 8) \mathrm{mV})$ were followed by an increase of the potential difference towards the end of the experiment in all animals.

Jejunal net transport data are shown in the Table. Water, sodium, and chloride net absorption was significantly reduced in group 3 $(\mathrm{p}<0.01)$, while transport in group 2 was not significantly different from that of the controls (group 1). Potassium absorption (groups 1 and 2) turned to net secretion in group 3 (Table).

\section{Discussion}

Atrial natriuretic peptide in pathophysiological doses has no effect on intestinal ion transport in normal human volunteers. ${ }^{910}$ Higher doses have been used in previous animal studies. ${ }^{4715-21}$ The present study in anaesthetised rats was designed to evaluate the intestinal response to increasing pharmacological doses of atrial natriuretic peptide. The larger dose produced a response. The resulting plasma concentrations were found to be in the higher range when compared with most other studies ${ }^{1521}$ and above the pathophysiological concentrations known to occur, for example, in congestive heart failure..$^{22}$ Possible toxicity of atrial natriuretic peptide was suggested when two rats died during the infusion. Data on controls, on the other hand, were not different from previously reported data. ${ }^{2324}$

Systolic blood pressure was reduced slightly in our controls compared with that in conscious animals, ${ }^{16}$ a known side effect of pentobarbitone anaesthesia. ${ }^{26}$ Similar low blood pressures were reached with both atrial natriuretic peptide doses after 30 minutes of infusion (Fig 2). Although the larger dose produced a more rapid decline in blood pressure, none of these differences was significant and no further changes were observed during the jejunal transport study. In a well designed study Seymour $e t a l^{18}$ infused rats with increasing doses of atrial natriuretic peptide $(0 \cdot 020-0 \cdot 1 \mathrm{nmol} / \mathrm{min} / \mathrm{kg})$. A maximum effect on the vascular system was found in the dose range $0 \cdot 06-0 \cdot 1 \mathrm{nmol} / \mathrm{min} / \mathrm{kg}$ intravenously, and even tenfold higher concentrations, as used in our study, did not further influence blood pressure. The moderate increase in blood pressure during the jejunal transport study might be interpreted as a volume dependent effect because it was also observed in the controls (Fig 2).

In vivo recording of colonic potential difference does not allow separation of electrogenic chloride secretion from electrogenic sodium absorption, as changes in electroneutral trans- port processes remain undetected. In contrast to the in vitro flux chamber data of Moriarty et al, ${ }^{27}$ performed with high serosal atrial natriuretic peptide concentrations $\left(10^{-5}-10^{-9} \mathrm{~mol} / \mathrm{l}\right)$, we could detect no changes in distal colonic potential difference. This virtually excludes a possible atrial natriuretic peptide-induced chloride secretion, which should have resulted in an acute increase in potential difference. The progressive increase in potential difference in all animals after 90 minutes (Fig 2) is most likely a mineralocorticoid effect, possibly induced by the anaesthesia and surgical procedure at the beginning of the experiment. ${ }^{28}$

Jejunal net absorption of water and electrolytes was reduced by $>50 \%$ only in group 3 (Table). The general hypotensive effect of atrial natriuretic peptide cannot explain this phenomenon as the smaller dose produced a similar hypotensive response but did not alter net jejunal transport (Fig 2). The very high pharmacological atrial natriuretic peptide dose may have initiated non-specific - for example, cholinergic, peptidergic - secretion or even cyclic guanosine monophosphate mediated processes. ${ }^{29}$ The net potassium secretion into the jejunum (Table) may be regarded as an index for impaired electrolyte absorption in parallel to electrogenic, for example $\mathrm{Cl}^{-}$, secretion, which is a common feature of intestinal epithelial transport but cannot be distinguished in in vivo net transport studies.

Blood volume could be an important 'trigger mechanism' to facilitate the effect of atrial natriuretic peptide on its target organs. ${ }^{17}$ In a recent study volume expansion by $10 \%$ with $5 \%$ albumin in the rat decreased jejunal water absorption by $70 \%$ as did a bolus intravenous injection of atrial natriuretic peptide $(1.6 \mathrm{nmol} /$ $\mathrm{kg}) .^{7}$ Atrial appendectomy blunted the effect of volume expansion on intestinal transport, providing strong evidence that atrial natriuretic peptide has an important role in intestinal water and electrolyte homoeostasis. Reflex inhibition of intestinal sympathetic nerve activity did not seem to play a major part in decreased fluid absorption after volume load. ' Interestingly, our data correspond well with these findings, with respect to comparable concentrations of intravenous atrial natriuretic peptide (group 3, Table).

Cyclic guanosine monophosphate has been shown to be an intracellular transmitter of atrial natriuretic peptide action in the guinea pig stomach ${ }^{30}$ and porcine colon. ${ }^{31}$ Its role in the intestine, however, has yet not been fully established. Studies in rats using volume expansion and low (pathophysiological) doses of atrial natriuretic peptide over longer time periods are indicated to further elucidate its role in the regulation of intestinal water and electrolyte transport as an integrated part of overall body fluid homoeostasis.

This study was supported by a grant from the Medical Research Council of New Zealand. The processing of the plasma samples for atrial natriuretic peptide analysis by the Department of Endocrinology, Princess Margaret Hospital, Christchurch, NZ is acknowledged with thanks.

This article is dedicated to Professor W Gerok (University of D-Freiburg Medical School) on the occasion of his 65th birthday. 
1 Humphreys MH, Laurence EE. The mechanism of decreased intestinal sodium and water absorption after acute volum expansion in the dog. $\mathcal{F}$ Clin Invest 1971; 50: 2355-67.

2 Richet G, Hornych A. The effect of an expansion of extracellular fluids on net $\mathrm{Na}$ flux in the jejunum of the rat. Nephron 1969; 6: 365-78.

3 de Bold AJ, Borenstein HB, Veress AT, Sonnenberg H. A rapid and potent natriuretic response to intravenous injection of atrial myocardial extract in rats. $L$ ife $S c i 1981 ; 28: 89$ 94.

4 Kanai Y, Ohnuma N, Matsuo H. Rat atrial natriuretic polypeptide increases net water, sodium and chloride
absorption across rat small intestine in vivio. $\mathcal{F}$ pn $\mathcal{F}$ absorption across rat sm

5 Gonvers JJ, Winistörfer B, Mirkovitch V, De Vane P, Brunne HR. Atrial natriuretic peptide decreases net water an sodium absorption in dog jejunum. Gastroenterology 1987 92: 1408 .

6 Matsushita K, Nishida J, Hironobu M, et al. Effects of atria natriuretic peptide on water and electrolyte movements at intestine circulation. Circulation 1988; 78: 285.

7 Petterson A, Jönsson CO. Effects of atrial natriuretic peptide (ANP) on jejunal net fluid absorption in the rat. Acta Physio Scand 1989; 136: 419-26.

8 Seeber AM, Vidal A, Carchio M, Karara L. Inhibition of water-sodium intestinal absorption by an atrial extract. $\mathrm{Can}$ f Physiol Pharmacol 1986; 64: 244-7.

9 Petritsch W, Holzer-Petsche U, Hinterleitner T, Krejs GJ Intravenous atrial natriuretic peptide does not affect wate and electrolyte transport in the human small intestine. Eur $\mathcal{F}$ Clin Invest 1989; 19: 272-7.

10 Brunner J, Lübcke R, Barbezat GO, Yandle TG, Espiner EA Atrial natriuretic peptide and water and electrolyte transport in the human jejunum. Gut 1991; 32: 635-9.

11 Dunag RD. Validation in awake rats of a tail-cuff method for measuring systolic pressure. $\mathcal{F}$ Appl Physiol 1973; 34: 279 82.

12 Lübcke $\mathbf{R}$, Haag $\mathrm{K}$, Berger $\mathrm{E}$, Knauf $\mathbf{H}$, Gerok W. Ion tan 251: G132-9.

13 Malawer SJ, Powell DW. An improved turbidometric analysis of polyethylene glycol utilizing an emulsifier. Gastroenterology 1967; 53: 250-6.

14 Yandle TG, Crozier IG, Nicholls MG, Espiner EA, Carne A Brennan S. Amino acid sequence of atrial natriuretic peptides in human coronary sinus plasma. Biochem Biophys Res Commun 1987; 146: 832-9.

15 Grimaldi R, Zini I, Agnati LF, Fuxe K, Härfstrand A. Intravenous administration of atriopeptin III affects arterial blood pressure diferentially in young and old male rats. Acto Physiol Scand 1987; 129: 525-8.

16 Campbell TH, Lightfoot BO, Sklar AH. Four-hour atria natriuretic peptide infusion in conscious rats: effects on urinary volume, sodium, and cyclic GMP (428 13). Proc Soc Exp Biol Med 1988; 189: 317-24.

17 Richards AM, Espiner EA, Ikram H, Yandle TG. Atria natriuretic factor in hypertension: bioactivity at norma plasma levels. Hypertension 1989; 14: 261-8.

18 Seymour AA, Smith III SG, Mazack EK. Effects of renal perfusion pressure on the natriuresis induced by atrial natriuretic factor. Am $\mathcal{F}$ Physiol 1987; 253. F234-8.

19 Seymour AA, Swerdel JN, Fennell SA, Delaney NG. Atria natriuretic peptides cleaved by endopeptidase are inactive in conscious spontaneously hypertensive rats. Life Sci 1988; 43: $2265-74$.

20 Sosa EA, Volpe M, Marion DN, et al. Relationship between renal hemodynamic and natriuretic effects of atria natriuretic factor. Am F Physiol 1986; 250: F520-4.

21 Zukowska-Grojec Z, Haas M, Kopin I, Zamir N. Interaction of atrial natriuretic peptide with the sympathetic and endocrine systems in the pithed rat. F Pharmacol Exp The 1986; 239: 480-7

22 Raine AEG, Firth JG, Ledingham JDG. Renal actions of atrial natriuretic factor. Clin Sci 1986; 76: 1-8.

23 Eskay R, Zukowska-Grojec Z, Haas M, Dave JR, Zamir N. Circulating atrial natriuretic peptides in conscious rats: regulation of release by multiple factors. Science 1986; 232 : regula 936 .

24 Kohno M, Clegg KB, Sambhi MP. Effects of volume chang on circulating $\mathrm{KB}$, Sambhi MP. Effects of volume change on circulating immunoreactive at

25 Biollaz J, Callahan LT, Nussberger J, et al. Pharmacokinetic of synthetic ANP in normal men. Clin Pharmacol Ther 1987 41: 671-7.

26 Gray D. Spontaneous hypertension in the neonatal rat. Clin Exp Hypertens [A] 1984; 4: 755-81.

27 Moriarty KJ, Higgs NB, Lees $M$, Tonge A, Warhurst G, Turnberg LA. Influence of atrial natriuretic peptide on mammalian large intestine Gastroenterology 1990; 98: 647 53.

28 Fromm $M$, Hegel $U$. Net ion fluxes and zero flux limited concentrations in rat upper colon and rectum during concentrations in rat upper colon and rectum during 1987; 408: 185-93.

29 Dale CL, Murad F. Atrial natriuretic factor receptor heterogeneity and stimulation of particulate guanylate cyclase and cyclic GMP accumulation. In: Rosenblatt M, Jacobs J, eds. Endocrinology and metabolism clinics of North America. Atrial natriuretic factor. Vol 16. Philadelphia: WB Saunders, 1987 $107-45$.

30 Cherner JA, Singh G, Naik L. Atrial natriuretic factor (ANF) activates membrane-bound guanylate cyclase of chief cells from guinea pig stomach. Gastroenterology 1990; 98: A486.

31 Argenzio RA, Liacos JA. Atrial natriuretic peptide inhibit neutral $\mathrm{Na}$ absorption and elicts anion secretion in mammalian colon. Gastroenterology 1990; 98: A536. 